\title{
CLIMATE SPATIALIZATION AND GENOTYPE-ENVIRONMENT INTERACTION EFFECTS ON WEANING WEIGHTS OF NELLORE CATTLE IN EXTENSIVE SYSTEMS IN TROPICAL REGIONS OF BRAZIL
}

\author{
EFEITOS DA ESPACIALIZAÇÃO CLIMÁTICA E INTERAÇÃO GENÓTIPO- \\ AMBIENTE SOBRE O PESO DA DESMAMA DE BOVINOS DA RAÇA \\ NELORE CRIADOS EM SISTEMAS EXTENSIVOS NO NORTE DO BRASIL.
}

\author{
Jorge Luis Ferreira ${ }^{1^{*}}$ \\ Fernando Brito Lopes ${ }^{2}$ \\ José Américo Soares Garcia ${ }^{3}$ \\ Maria Paula Beiriz Silva ${ }^{1}$ \\ Leandro Lopes Nepomuceno ${ }^{4}$ \\ Ednira Gleida Marques ${ }^{5}$ \\ Marcelo Côrrea da Silva ${ }^{6}$ \\ 1 Universidade Federal do Tocantins, Araguaína, TO, Brazil. \\ ${ }^{2}$ College of Agricultural \& Life Sciences - University of Wisconsin, Wiscosin, USA. \\ 3Universidade de Brasília, Brasília, DF, Brazil. \\ ${ }^{4}$ Universidade Federal de Goiás, Goiânia, GO, Brazil. \\ ${ }^{5}$ Associação Brasileira de Criadores de Zebu - ABCZ, Uberaba, MG, Brazil. \\ 6Universidade Federal da Grande Dourados, Dourados, MS, Brazil. \\ *Author for correspondence - jlferreira@mail.uft.edu.br
}

\begin{abstract}
Depending on the environmental differences among the regions, the phenotypic expression in beef cattle may significantly vary between the progenies of the same sire, and this is an important rule to identify the best animal. Thus, this study was carried out to spatialize environmental factors that may help to compare and discriminate the states of Maranhão, Pará, and Tocantins and also to check for genotype $\mathrm{x}$ environment interaction ( $\mathrm{G} \times \mathrm{E}$ interaction) in these regions. The environmental variables analyzed were: maximum temperature; minimum temperature; mean temperature; precipitation; normalized difference vegetation index; relative humidity; altitude; and index of temperature and humidity. Records of weaning weight of Nellore cattle raised on pasture were collected between the years of 1997 and 2007. The dataset was constituted of 21.117 animals, progenies of 161 sires. (Co)variance components and breeding values were estimated using the multiple-trait derivative-free restricted maximum likelihood method. Multivariate spatialization revealed clear distinction among the States of Maranhão, Pará, and Tocantins and allowed the identification of important environmental variables for discrimination. The estimate for direct heritability showed moderate magnitudes and were $0.22 \pm 0013,0.26 \pm 0.021$, and $0.29 \pm 0023$, for the
\end{abstract}


States of Maranhão, Pará, and Tocantins, respectively. The estimates of correlation between the breeding values, predicted in different States, as well as the genetic correlation for weaning weight showed that sire ranks changed among the States, indicating $G \times E$ interaction. There was a variation of the genetic response of the progeny, depending on the sire and on the State. Thus, the $G$ $\mathrm{x} E$ interaction should be accounted for in the genetic evaluation of sires and the performance of Nellore cattle under extensive breeding systems in tropical regions of Brazil.

Keywords: animal breeding; canonical correlation; cluster; heritability; Zebu.

\section{Resumo}

A expressão fenotípica pode variar significativamente sob diferenças climáticas e deve ser um motivo de preocupação na identificação e seleção de animais superiores no Brasil. Dessa forma, no presente estudo objetivou-se espacializar fatores ambientais para discriminar os estados do Maranhão (MA), Pará (PA) e Tocantins (TO) e verificar presença de interação genótipo-ambiente (IGA) para peso ao desmame em rebanhos bovinos da raça Nelore localizados nestes Estados. As variáveis ambientais analisadas foram: temperatura máxima; temperatura mínima; temperatura média; precipitação; índice vegetativo normalizado; umidade relativa; altitude e índice de temperatura e umidade. Os registros de peso a desmama de bovinos da raça Nelore criados à pasto foram coletados entre os anos de 1997 e 2007 e o conjunto de dados constituído por 21.117 animais, filhos de 161 touros comuns aos Estados do MA, PA e TO. As estimativas para herdabilidades direta apresentaram magnitudes moderadas, com valores de 0,22 $\pm 0,013$ (MA), 0,26 $\pm 0,021$ (PA) e $0,29 \pm 0,023$ (TO). As variáveis ambientais discriminaram bem os Estados e as estimativas revelaram variação da resposta genética da progênie, dependendo do pai e do Estado em questão. As estimativas de correlações genéticas para peso ao desmame indicaram forte presença de interação genótipo-ambiente.

Palavras-chave: correlação canônica; cluster; herdabilidade; produção animal; Zebu.

Received on January $28^{\text {th }}, 2016$.

Acceped on December $5^{\text {th }}, 2016$.

\section{Introduction}

The variation of environmental factors and effects is an issue for cattle production in Brazil, considering the enormous magnitude of beef production in this country. Meat production is associated to the phenotype of animals, which is the relationship between genetic and environmental components ${ }^{(1)}$. Phenotypical expression may vary significantly under climatic variation and should be a matter of concern for the identification and selection of superior animals in Brazil $^{(2,3)}$.

Considering G x E interaction, Cooper and Dellacy ${ }^{(4)}$ reported that only when the genetic correlation among environments is less than one does the $\mathrm{G} \times \mathrm{E}$ interaction restrain response to selection. In this sense, different thresholds have been suggested to measure the significance of this type of interaction ${ }^{(5)}$. Frstly, however, it seems that checking and discussing this phenomenon is the 
most fortunate way to encourage the adoption of this approach in Brazil.

Climate and production systems vary significantly throughout the vast tropical regions of Brazil. Therefore, consideration of $\mathrm{G} \times \mathrm{E}$ interaction may impact significantly the efficiency of genetic improvement programs over the years. An effort towards research on $\mathrm{G} \times \mathrm{E}$ interaction will come up against several bottlenecks at the time of implementation. However, when put into practice the advantage is that genetic evaluations are delivered for each specific environment. This has been demonstrated in the case of Nellore cattle breeding in several regions of Brazil ${ }^{(2,6-10)}$.

The States of Maranhão, Pará, and Tocantins are considered a privileged area to breed Nellore cattle under extensive pastures and tropical conditions in South America, mainly because of the high sunlight incidence and the soil conditions. The investigation was motivated under the hypothesis that the large extent and heterogeneity of the Brazilian landscape plays a role on the genetic evaluation of sires and the performance of Nellore Cattle raised on pasture in tropical regions of Brazil.

\section{Materials and Methods}

The analysis was scheduled and divided into two different procedures. First, an ecologic characterization was undertaken to detect environmental patterns of diversity. Second, a genotype $\mathrm{x}$ environment interaction ( $\mathrm{G} \times \mathrm{E}$ interaction) approach was carried out to verify any environmental effect on both the phenotype and genotype of Nellore cattle.

The data set was composed of information describing the environmental condition of 498 Brazilian cities distributed in the States of Maranhão (217), Northeast of Brazil, Pará (143), and Tocantins (138), both located in the North Region of Brazil (Figure 1). The States of Maranhão and Tocantins are located in a transition zone between the Amazon and the Savannah biome ${ }^{(11)}$.

The environmental variables analyzed were the annual average for maximum temperature (MAXT); minimum temperature (MINT); mean temperature (MT); precipitation (PR); normalized difference vegetation index (NDVI); relative humidity $(\mathrm{RH})$; altitude $(\mathrm{AL})$, and index of temperature and humidity (ITH). All environmental variables were standardized by computing the $\mathrm{Z}$ scores separately for each pair of States by standardizing life-expectancy data to a mean of 0 and a standard deviation of $1^{(12)}$. Study variables (Table 1) were obtained by the Brazilian Institute of Geography and Statistics, National Institute of Meteorology, National Institute for Space Research, United States Geological Survey, and the United Nations Program for Development.

The following multivariate analyses were used in this study: discriminant analysis, which computes various discriminant functions for classifying observations; canonical analysis, used to find linear combinations of the quantitative variables that best summarize the differences among the classes; and, stepwise selection, used to find a subset of quantitative variables that reveal most of the differences among classes. Also, cluster analysis was used to sort variables into groups which were not defined a priori, so those objects in a given cluster tend to be similar to each other in some sense, and objects in different clusters tend to be dissimilar. Hierarchical clustering was performed using Ward's minimum-variance method, in which the distance between two clusters is based on the 
sum of squares between them added up over all the variables. At each generation, the within-cluster sum of squares is minimized over all partitions obtainable by merging two clusters from the previous generation. To visualize the results from the cluster analysis, a dendrogram was drawn ${ }^{(12)}$.

Table 1. Descriptive statistic for the environmental variable in Maranhão, Pará and Tocantins States

\begin{tabular}{|c|c|c|c|c|c|c|c|c|c|}
\hline \multirow{2}{*}{ Variable } & TMIN & TMAX & $\mathrm{AT}$ & TM & PR & ALT & NDVI & UR & ITU \\
\hline & \multicolumn{9}{|c|}{ Maranhão } \\
\hline Mcan & 27.33 & 38.06 & 10.73 & 32.41 & 1791.98 & 246.34 & 0.4 & 50.09 & 81.31 \\
\hline SD & 0.71 & 0.98 & 0.28 & 0.84 & 336.47 & 71.18 & 0.01 & 9.73 & 2.14 \\
\hline $\mathrm{CV}$ & 2.59 & 2.59 & 2.59 & 2.59 & 18.78 & 28.9 & 1.46 & 19.42 & 2.64 \\
\hline CL $2.5 \%$ & 27.23 & 37.93 & 10.69 & 32.3 & 1746.96 & 236.82 & 0.4 & 48.79 & 81.02 \\
\hline \multirow[t]{2}{*}{ CL $9.75 \%$} & 27.42 & 38.19 & 10.77 & 32.52 & 1837 & 255.87 & 0.4 & 51.4 & 81.59 \\
\hline & \multicolumn{9}{|c|}{ Pará } \\
\hline Mean & 31.78 & 37.45 & 5.66 & 33.95 & 2197.64 & 726.03 & 0.81 & 69.33 & 87.08 \\
\hline SD & 1.06 & 1.25 & 0.19 & 1.14 & 91.09 & 145.36 & 0.01 & 10.26 & 2.64 \\
\hline $\mathrm{CV}$ & 3.34 & 3.34 & 3.34 & 3.34 & 4.14 & 20.02 & 1.24 & 14.79 & 3.04 \\
\hline CL $2.5 \%$ & 31.61 & 37.24 & 5.63 & 33.76 & 2182.58 & 702 & 0.81 & 67.63 & 86.65 \\
\hline \multirow[t]{2}{*}{ CL $9.75 \%$} & 31.96 & 37.65 & 5.69 & 34.14 & 2212.7 & 750.06 & 0.81 & 71.02 & 87.52 \\
\hline & \multicolumn{9}{|c|}{ Tocantins } \\
\hline Mcan & 29.87 & 35.2 & 5.32 & 31.91 & 1091.64 & 299.81 & 0.41 & 54.95 & 81.51 \\
\hline SD & 1.14 & 1.34 & 0.2 & 1.21 & 101.55 & 63.7 & 0.01 & 4.85 & 1.9 \\
\hline $\mathrm{CV}$ & 3.8 & 3.8 & 3.8 & 3.8 & 9.3 & 21.25 & 2.51 & 8.82 & 2.33 \\
\hline CL $2.5 \%$ & 29.68 & 34.97 & 5.29 & 31.71 & 1074.54 & 289.08 & 0.41 & 54.13 & 81.19 \\
\hline CL $9.75 \%$ & 30.07 & 35.42 & 5.36 & 32.12 & 1108.73 & 310.53 & 0.41 & 55.76 & 81.83 \\
\hline
\end{tabular}

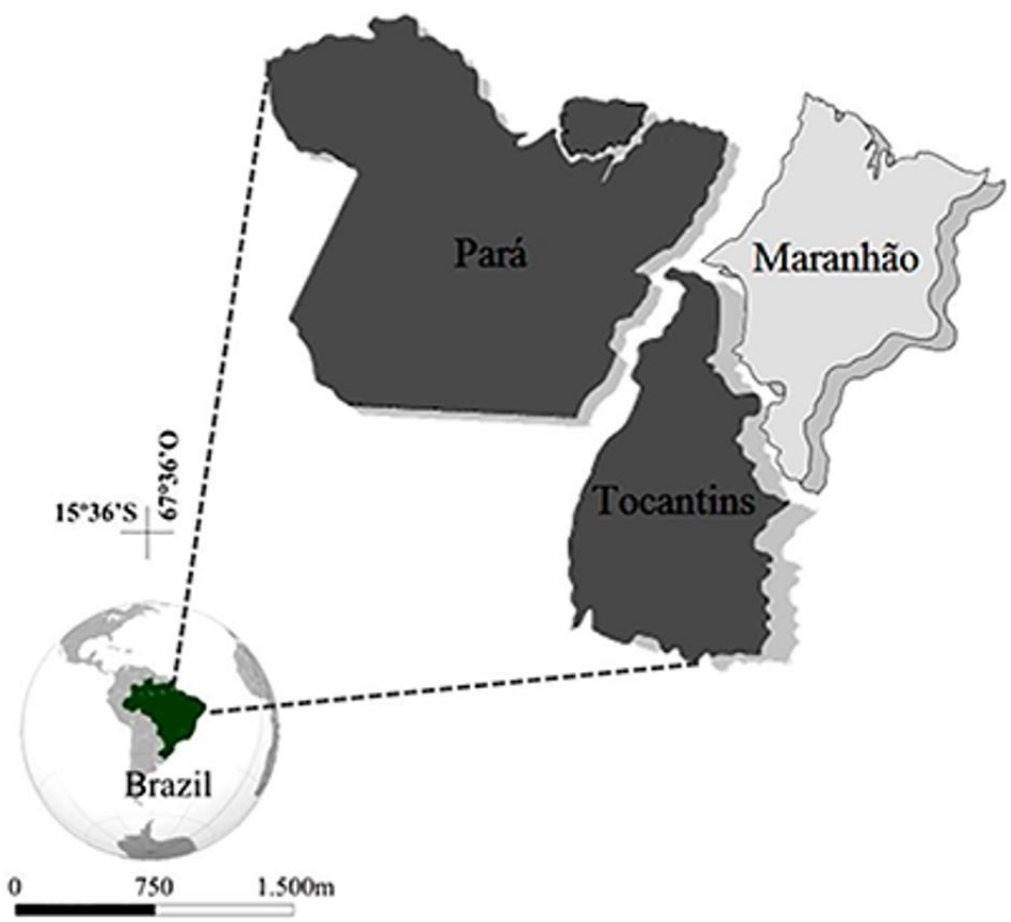

Figure 1.Political map illustrating the States of Maranhão, Pará and Tocantins in the Northeast and North Region of Brazil. 
Performance records of 21,117 animals born in the states of Maranhão (3.653), Pará (8.132), and Tocantins (9.332) from 1997 to 2007 were used to study the effect of G x E interaction. Phenotypic data consisted of standardized weights (205 days of age, W205) registered in the genetic improvement program led by the Brazilian Association of Zebu Breeders (ABCZ). The progenies included in the analysis were the offspring of 161 sires and 17.760 cows, bred in the States of Maranhão (2.966), Pará (6.535), and Tocantins (8.159). The number of herds from each State was $142 ; 229$; and 223, respectively. As exclusion criteria for males, only sires that had progeny in all three States were included in the analysis.

The univariate and bivariate models included the random direct genetic effects, with the maternal genetic effects and the maternal permanent environmental effects, as well as the fixed effects of contemporary group (herd, sex, season, and year of birth), and age of dam at calving as a covariate (linear and quadratic effects). As suggested by Falconer and Mackay ${ }^{(1)}$, the expression of the same trait in two environments can be considered as two different traits, and the genetic correlation between them can be estimated in the same way as for any two correlated traits, using bivariate analysis. To estimate genetic parameters for W205 the animal model was:

$$
y=X \beta+Z_{1} a+Z_{2} m+Z_{3} m p e+e
$$

where, $\boldsymbol{y}$ is the vector of observations (W205); $\boldsymbol{\beta}$ is the vector of fixed effects in the model, associated with the incidence matrix X; $\boldsymbol{a}$ is the vector of random direct genetic effects associated with the incidence matrix $Z_{1} ; \boldsymbol{m}$ is the vector of maternal genetic effects associated with the incidence matrix $\mathrm{Z}_{2}$; mpe is the vector of the random maternal permanent environmental effects associated with the incidence matrix $\mathrm{Z}_{3}$; and, $\boldsymbol{e}$ is the vector of the random residual effects.

The maternal and the direct genetic effects are assumed to be correlated, while the residual and permanent environment effects are not, nor are they correlated with the genetic effects. Computations of direct genetic $\left(\sigma_{a}^{2}\right)$, maternal genetic $\left(\sigma_{m}^{2},\right)$ covariance between the direct and maternal genetic $\left(\sigma_{a m}\right)$, maternal permanent environmental $\left(\sigma_{m p e}^{2}\right)$, and residual variances $\left(\sigma_{e}^{2}\right)$ were carried out using the MTDFREML software ${ }^{(13)}$. The following (co)variance components and parameters were calculated as in Willham ${ }^{(22)}$ : phenotypic variance $\left(\sigma_{p}^{2}=\sigma_{a}^{2}+\sigma_{m}^{2}+\sigma_{a m}+\sigma_{p e}^{2}+\right.$ $\left.\sigma_{e}^{2}\right)$, direct heritability $\left(h_{a}^{2}=\sigma_{a}^{2} / \sigma_{p}^{2}\right)$, and maternal heritability $\left(h_{m}^{2}=\sigma_{m}^{2} / \sigma_{p}^{2}\right)$. Breeding values were estimated using the Restricted Maximum Likelihood Method - REML, with the MTDFREML software $^{(13)}$.

The effect of $\mathrm{G} \times \mathrm{E}$ interaction was also evaluated using the change in ranking of sires. The sires were ranked based on their breeding values (BV) in each State. The similarity between the rankings

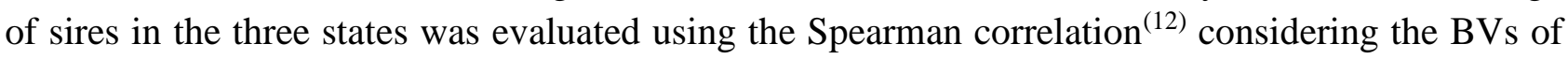
the 161 bulls in each separate State.

\section{Results}

The multivariate discriminant analysis revealed that discrimination between States is consistent, reinforcing the hypothesis that phenotypical expression, concerning cattle production and 
productivity, may be affected with different intensities throughout the Brazilian landscape. The environmental variables used to characterize climate conditions were enough to guarantee no misclassifications $(0 \%)$ when assigning any city into their respective State of origin (Table 2).

Table 2. Percentage of environmental factors classificd in cach group

\begin{tabular}{ccccc}
\hline From group & Maranhão & Pará & Tocantins & Total of Citics \\
\hline Maranhão & 100 & 0 & 0 & 217 \\
Pará & 0 & 100 & 0 & 143 \\
Tocantins & 0 & 0 & 100 & 138 \\
\hline Error level & 0 & 0 & 0 & 498 \\
\hline
\end{tabular}

The environmental information revealed to be a real source of variation between the States of Maranhão, Pará, and Tocantins, but some variables where more important than others $(\mathrm{p}<0.05)$ (Table 3).

Table 3. Environmental variables that best discriminate States in the comparison between Maranhão, Pará and Tocantins

\begin{tabular}{lcc}
\hline & Maranhão & Tocantins \\
\hline Pará & MINT MAXT MT & MINT MAXT ITH \\
& PR AL NDVI & PR AL NDVI \\
Maranhão & & MINT MAXT ITH RH \\
& & PR AL NDVI \\
\hline
\end{tabular}

MAXT: maximum temperature, MINT: minimum temperature; MT: mean temperature; PR: precipitation; NDVI: normalized difference vegetative index; RH: relative humidity; AL: altitude and ITH: index of temperature and humidity

In parallel, the canonical analysis plot also made evident that the cities from the same State group up together according to the similarity (Figure 2).

The distance between the clusters (Ward's Minimum-Variance Method) showed that the difference between Maranhão and Pará is greater than the difference between Maranhão and Tocantins (Figure 3). This result is probably due to the fact that the Amazon Forest is more abundant in Pará than in Maranhão and Tocantins, which are both assigned to the Cerrado Forest ecosystem. The canonical analysis was also able to point out the variables that best discriminate the three States, which presented strong correlation with TMAX, TMIN, and NDVI, respectively (Figure 4). 


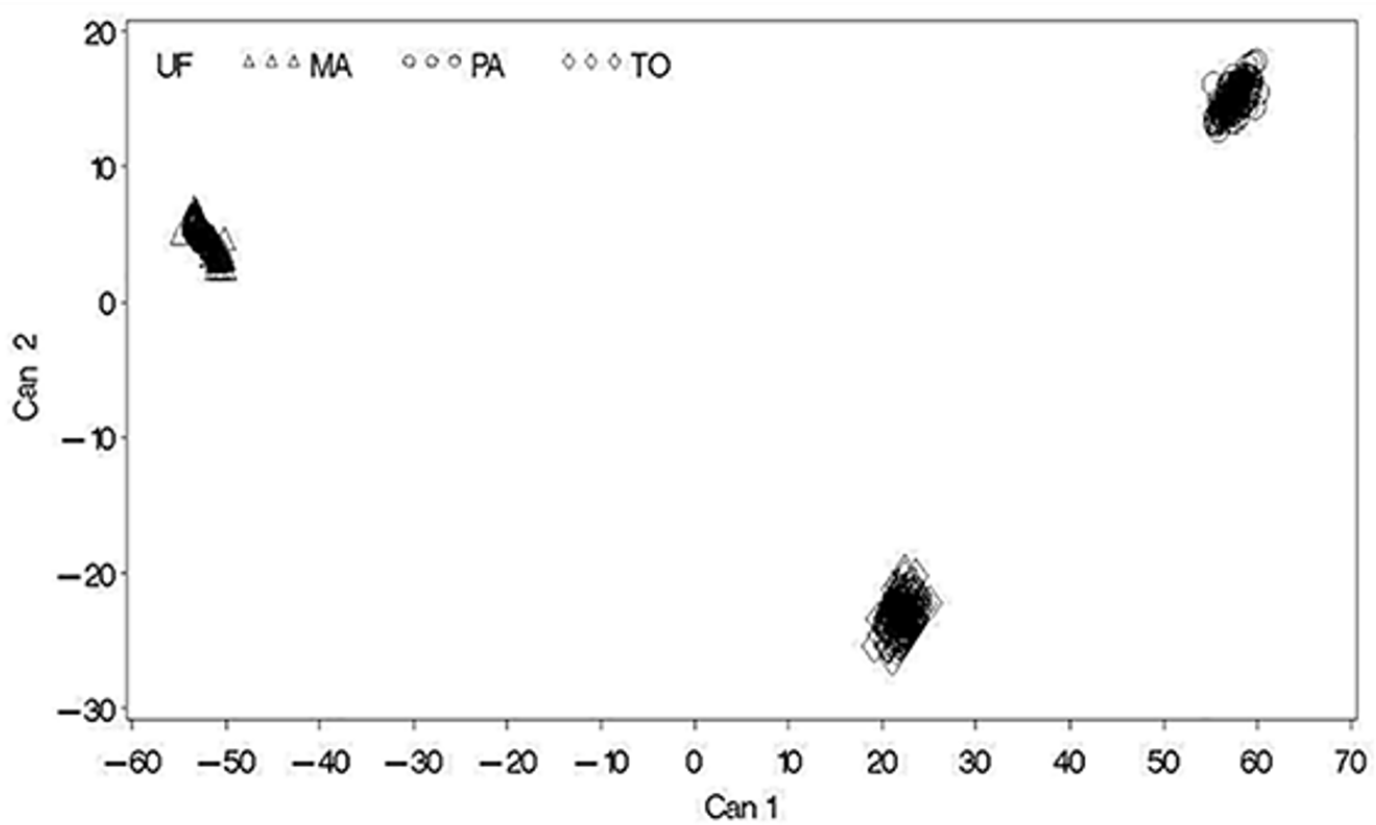

Figure 2. Graphical representation of canonical analysis considering 8 environmental variables and 498 cities located in Maranhão (MA), Pará (PA) and Tocantins (TO).

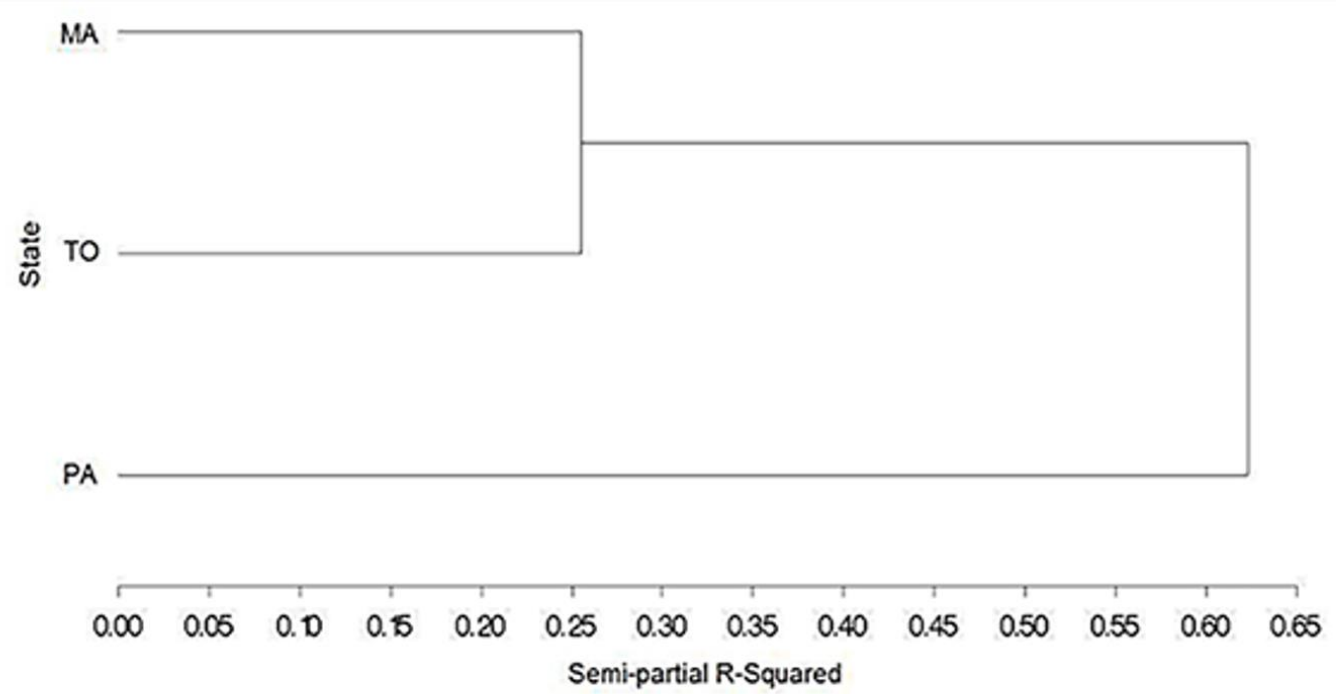

Figure 3. Tree diagram of distances between States of Maranhão (MA), Pará (PA) and Tocantins (TO). 


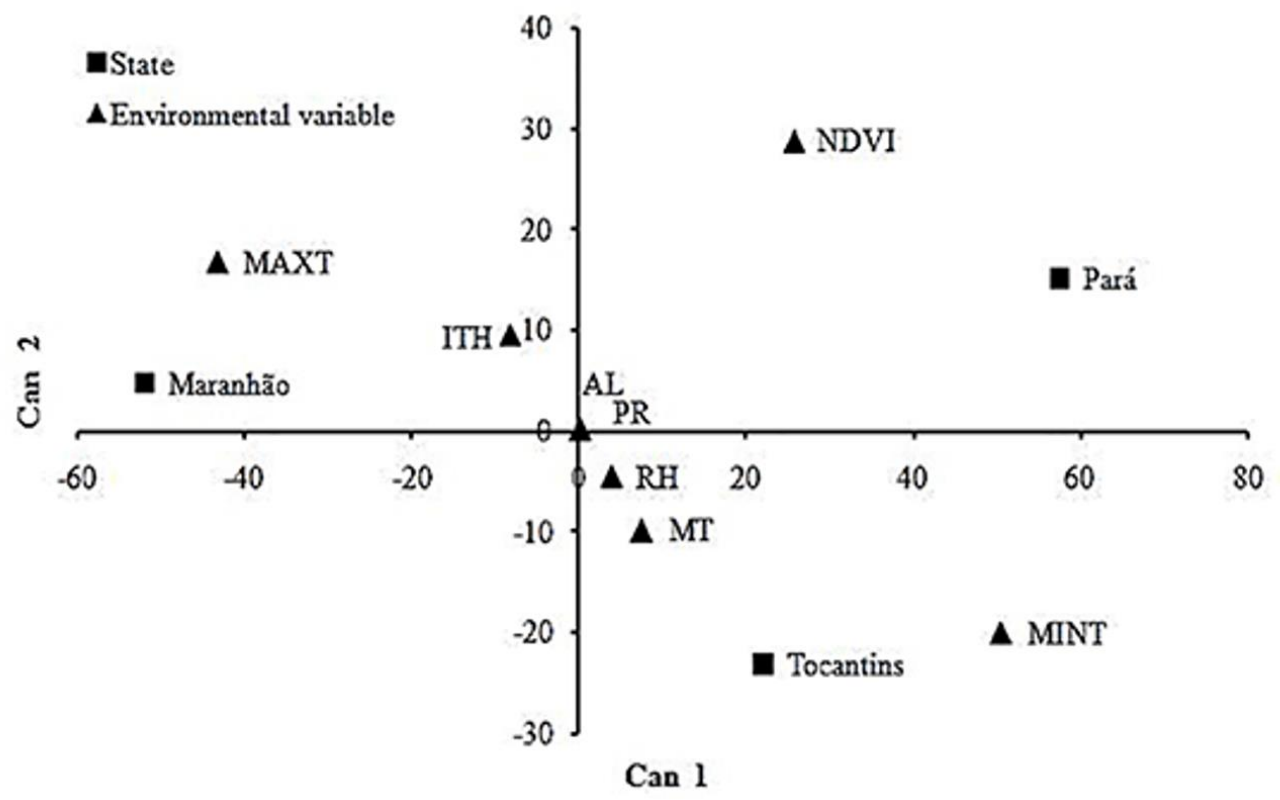

Figure 4. Graphical representation of canonical means revealing correlation estimates between environmental variables and three States of Brazil. MAXT: maximum temperature, MINT: minimum temperature; MT: mean temperature; PR: precipitation; NDVI: normalized difference vegetative index; RH: relative humidity; AL: altitude and ITH: index of temperature and humidity.

The multivariate analysis showed that the States of Maranhão, Pará, and Tocantins have environmental peculiarities significant enough to reveal strong discrimination. Under this condition, the selection of sires with progeny in all three States was the subsequent step to verify environmental influences on both the phenotype and genotype of the animals raised in these regions.

The estimates for direct heritability showed moderate magnitudes and the weaning weights among the three States of Brazil revealed to be different $(\mathrm{P}<0.01)$ (Table 4). The difference in magnitude of these estimates is an indication that the phenotypic response of the progeny of one sire depends on the political region under evaluation. The maternal ability expresses the aptitude of cows to care for their progeny. Besides being influenced by many factors, this trait has great importance in breeding programs ${ }^{(2)}$. The estimates pointed low maternal heritability, indicating that maternal ability suffers great influence of the environment effect and that the performance of daughters of the same sire varies according to the State under consideration.

Assuming that the performance of sires varies when exposed to different environments, the draw of the top $10 \%$ sires is helpful to illustrate the variation on the expected performance of progenies (Figure 5). Estimated progeny difference (EPD) represent the divergence in the expected performance of the progeny of one sire compared to other sires, included in the same genetic evaluation program. Results in Figure 5 reinforce the statement that environmental diversity has been interfering significantly in the genetic evaluation of Nellore sires in extensive breeding systems in tropical regions of Brazil. It is also important to pay attention that besides the correlations estimated using the top $10 \%$ of sires are considered high, less than $20 \%$ of these sires where repeated. Thus, such high correlations are due to similar trend, not due to existence of the same sire, which were all ranked differently in each State. As an example, the best sire in Tocantins 
$\left(\mathrm{EPD}=12 \mathrm{~kg}\right.$ and rank $\left.=1^{\circ}\right)$ had progenies only in Maranhão State $\left(\mathrm{EPD}=1.04 \mathrm{~kg}\right.$ and $\left.\operatorname{rank}=11^{\circ}\right)$; the best sire in Pará $\left(\mathrm{EPD}=4.98 \mathrm{~kg}\right.$ and $\left.\mathrm{rank}=1^{\circ}\right)$ was found only in Maranhão $(\mathrm{EPD}=1.51 \mathrm{~kg}$ and rank $\left.=5^{\circ}\right)$; and, the best sire in Maranhão $\left(\mathrm{EPD}=1.97 \mathrm{~kg}\right.$ and rank $=1^{\circ}$ ) had progenies in both States of Tocantins $\left(\mathrm{EPD}=6.61 \mathrm{~kg}\right.$ and $\left.\operatorname{rank}=4^{\circ}\right)$ and Pará $\left(\mathrm{EPD}=3.40 \mathrm{~kg}\right.$ and $\left.\operatorname{rank}=7^{\circ}\right)$.

Table 4. Weaning weight, standard deviation, coefficient of variation and heritability for direct and maternal effects for standardized weights at 205 days of age in Nellore calves

\begin{tabular}{lrrr}
\hline \multicolumn{1}{c}{ Parameter } & \multicolumn{1}{c}{ Maranhão } & \multicolumn{1}{c}{ Pará } & \multicolumn{1}{c}{ Tocantins } \\
\hline Weaning weight $(\mathrm{kg})$ & $167.18^{\mathrm{b}}$ & $168.97^{\mathrm{a}}$ & $165.91^{\mathrm{c}}$ \\
Standard deviation $(\mathrm{kg})$ & 21.02 & 20.49 & 20.87 \\
Coefficient of variation $(\%)$ & 12.57 & 12.1 & 12.58 \\
Direct heritability $\left(\mathrm{h}^{2} \mathrm{a}\right)$ & $0.22( \pm 0.013)$ & $0.26( \pm 0.021)$ & $0.29( \pm 0.023)$ \\
Maternal heritability $\left(\mathrm{h}^{2} \mathrm{~m}\right)$ & $0.09( \pm 0.053)$ & $0.06( \pm 0.041)$ & $0.12( \pm 0.061)$ \\
\hline
\end{tabular}

ts Different lowercase superscripts for weaning weight indicate statistically significant difference $(\mathrm{p}<0.001)$ by Tukey test

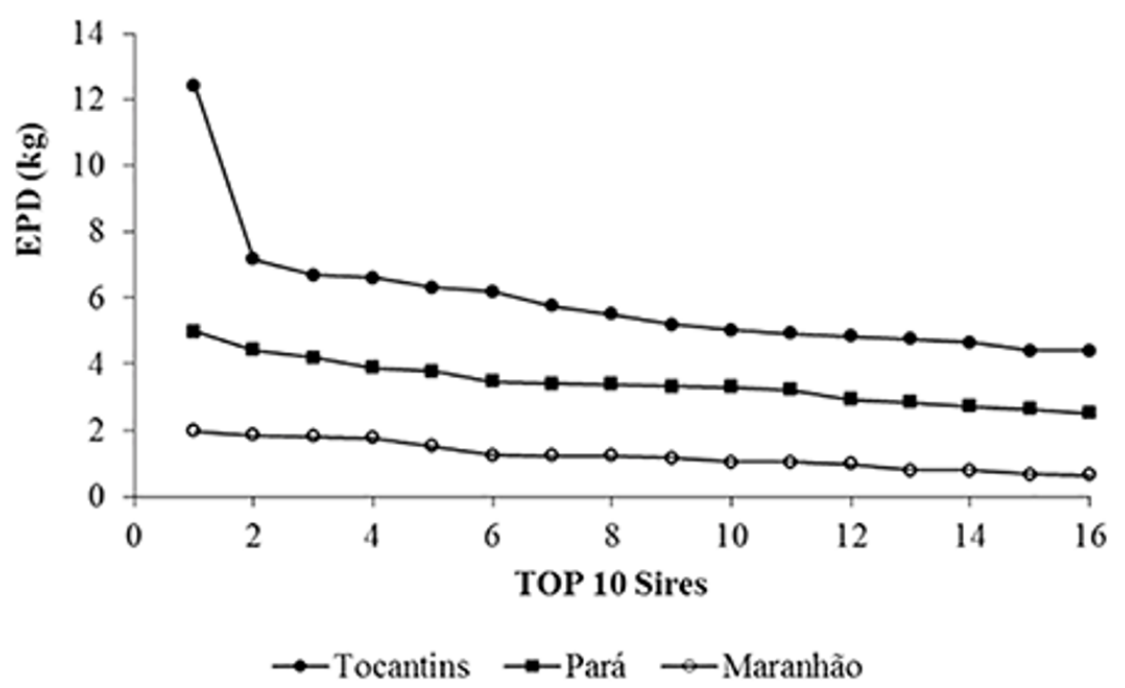

Figure 5. Expected progeny difference (EPD)for the top $10 \%$ sires for weaning weight in three States of Brazil.

Ranking correlations between the breeding values of sires, predicted for pairs of States, revealed the effect $G \times$ E interaction on selection for weaning weight at 205 days (Table 5). The magnitude of the genetic correlations between States was high ( 0.70 to 0.82$)$ in all cases. In the absence of $G \times E$ interaction, the expected genetic correlation across environments is one. In this sense, even using the top $10 \%$ or all animals, the best bulls differ among the States.

Ibi et al. ${ }^{(5)}$ suggested the $\mathrm{G} \times \mathrm{E}$ interaction is of biological and agricultural importance if the genetic correlation for the same trait in different environments is less than 0.80 . With this threshold, only estimates of genetic correlations for weaning weight were above the threshold of biological 
importance of $\mathrm{G} \times \mathrm{E}$ interaction (Table 5). Thus, this provides evidence that $\mathrm{G} \times \mathrm{E}$ interaction for this trait in the three States was biologically significant enough to allow abundant re-ranking of animals based on estimated breeding values (Figure 6). This indicates a limitation point for using weaning weight data from different States in a nationwide genetic evaluation scheme based on predicted breeding values because such approach leads to important changes in the ranking of sires. The stability of breeding values for weaning weight across all three States is illustrated in Figure 6 and is related to the variability of the genotypes throughout different environments.

Table 5. Estimates of the Spearman correlation between the breeding values of common Nellore sires and estimates of the genetic correlation between weaning weights of Nellore calves in Maranhão, Pará and Tocantins

\begin{tabular}{lcccccc}
\hline \multirow{2}{*}{ Geographical area } & \multicolumn{3}{c}{ Spearman corrclation } & \multicolumn{2}{c}{ Genctic corrclation ${ }^{1}$} \\
\cline { 2 - 7 } & \multicolumn{2}{c}{ All sires } & TOP 10\% sires & Pará & Tocantins \\
\hline Pará & Tocantins & Pará & Tocantins & & \\
\hline Maranhão & $0.33^{* * *}$ & $0.21^{* *}$ & $0.96 * * *$ & $0.78 * * *$ & $0.78 \pm 0.06$ & $0.70 \pm 0.09$ \\
Pará & & $0.39 * * *$ & & $0.87 * * *$ & & $0.82 \pm 0.03$ \\
\hline
\end{tabular}

$* *(p<0.01) ; * * *(p<0.001)$, ' Estimated using DFREML

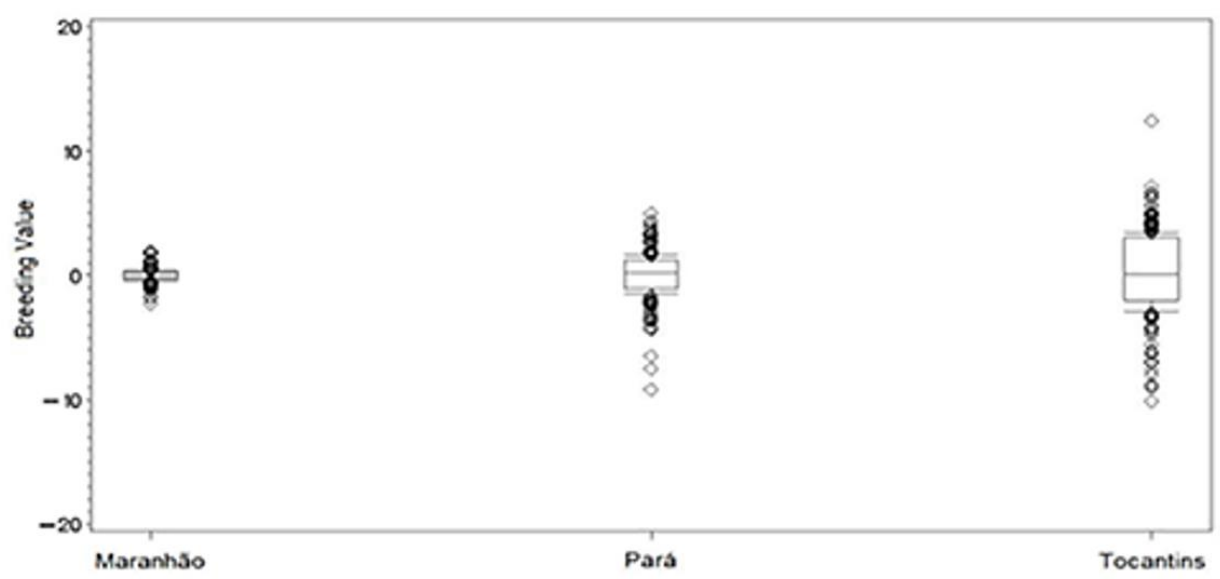

Figure 6. Stability of breeding values for weaning weight across States using 161 common sires of 23, 51 and 58 calves per sire in Maranhão, Pará and Tocantins, respectively.

\section{Discussion}

The fine discrimination of States in terms of environmental characteristics is a prior indication that, in some way, genetic and phenotypic expression of Nellore cattle might be influenced by the climatic conditions of the three States of Brazil.

The environmental peculiarities identified by the multivariate approach may be strongly related to 
the genetic results, represented by changes in the relative order of the ranking of sires among States. These results corroborate Lopes et al. ${ }^{(2)}$ and Toral et al. ${ }^{(7)}$. In practice, the implication is that a sire presenting satisfactory results for the weaning weight of the progenies in one region may have poor performances elsewhere. For this purpose, it would probably be necessary to carry out separate breeding value estimates for sires in regions where ranking variation is more intense.

Small magnitudes of the Spearman correlation estimates revealed little similarity of the ranking of sires among States. The genetic correlation estimates were high, but not strong enough to discard the assumption of $\mathrm{G} \times \mathrm{E}$ interaction. The presence of $\mathrm{G} \times \mathrm{E}$ interaction means that inadequate selection of sires may occur if the interaction effect is not accounted for. This is crucial considering that genetic progress is dependent on the additive genetic effect of the selected sires along generations.

In the presence of $\mathrm{G} \times \mathrm{E}$ interaction, the optimization of genetic improvement also requires consideration to the stability of the sires selected for reproduction. The variation of the breeding values among States (stability of sires) may be used as criteria for the ranking and the selection of superior sires ${ }^{(14)}$. Stability is related to the variability of the genotypes throughout different environments. Higher stabilities are associated to lower environmental sensibility of the genotypes, which may help as a conservative strategy for the selection of sires. Under G x E interaction, sires that generate more similar progeny in different environments are considered more stable. However, the selection of the steadiest genotypes does not necessarily imply in better performance of the progeny (weaning weights) in all environments.

Animal performance can be affected by G x E interaction and environmental sensitivity ${ }^{(3,15-17)}$. The accuracy of the selection process depends on adjusting selection criteria to local environment effects $^{(18)}$. So, estimating environmental effects on productive traits reduces information bias and improves the accuracy of the results. But most importantly, it is essential to generate higher production levels, consistent and appropriate to the local circumstance.

Adjusting genetic material to the local environmental conditions can be considered as an effort towards more sustainable production systems. This more holistic approach may have positive consequences in the differentiation of breeding goals ${ }^{(16)}$. Considering the increased privatization scenario of breeding companies and the amplified trade of breeding stock, empowered by globalization, the differentiation in breeding goals may play an important role on the maintenance of worldwide genetic variability in domestic animals ${ }^{(19)}$. Not only the present heterogeneity of production circumstances are in concern, but also the uncertainty and the associated risk about future circumstances, like global warming. Climate characterization and $\mathrm{G} x \mathrm{E}$ interaction appraisals may help to encourage and map the differentiation of breeding goals and the maintenance of diverse breeding stocks ${ }^{(20)}$.

Concepts of stability, efficiency, and performance have been reported repeatedly in the debate concerning genetic improvement strategies and the success of breeding programs in diversifying environments ${ }^{(16,21)}$. However, the debate still stands on the fact that most breeding programs aim for improvements in productivity ${ }^{(15)}$, apparently disregarding the fact that the success of these programs require also the consideration of environmental traits ${ }^{(3)}$. To overcome this impasse, animal breeding programs should be designed to account for a more satisfactory level of factors that may influence 
animal production across the regions of $\operatorname{Brazil}^{(3)}$.

\section{Conclusion}

The environmental components were important and sufficient to reveal fine discrimination among the States of Maranhão, Pará, and Tocantins. This emphasizes the climatic specificity and diversifying conditions of the tropical extensive systems where Nellore cattle are produced in Brazil. The identification of genotype $\mathrm{x}$ environment interaction for weaning weights is appealing for the consideration of this effect on the genetic evaluation of sires in Brazil.

\section{Acknowledgements}

The authors are grateful to the Federal University of Tocantins (Financial support process Propesq/UFT No. 21/2014), the Brazilian Association of Zebu Breeders (ABCZ), the Brazilian Institute of Geography and Statistics, the National Institute of Meteorology, the National Institute for Space Research and the United States Geological Survey for the phenotypic and environmental datasets provided for this study.

\section{References}

1. Falconer DS, Mackay TFC. Introduction to quantitative genetics. Longmans Green: Harlow, 1996. 386.

2. Lopes JS, Rorato PRN, Weber T, Boligon AA, Comin JG, Dornelles MDA. Efeito da interação genótipo x ambiente sobre o peso ao nascimento, aos 205 e aos 550 dias de idade de bovinos da raça Nelore na Região Sul do Brasil. Revista Brasileira de Zootecnia. 2008;37(1), 54-60.

3. McManus C, Cobuci J, Braccini Neto J, Paiva S. Decision making in animal breeding programs and their consequences for animal production. Revista Brasileira de Reprodução Animal. 2011;35(2), 69-76.

4. Cooper M,Delacy IH. Relationships among analytical methods used to study genotypic variation and genotype-by-environment interaction in plant breeding multi-environment experiments. Theoretical and Applied Genetics. 1994;88(5), 561-572.

5. Ibi T, Hirooka H, Kahi AK, Sasae Y, Sasaki Y. Genotypex environment interaction effects on carcass traits in Japanese Black cattle. Journal of animal science. 2005;83(7), 1503-1510.

6. Ferreira VC, Penna VM, Bergmann JA, Torres RA. Interaçäo genótipo-ambiente em algumas características produtivas de gado de corte no Brasil. Arquivo Brasileiro de Medicina Veterinária e Zootecnia. 2001;53(3), 385-392.

7. Toral FLB,Silva LOC,Martins EN. Interação genótipo x ambiente em características de crescimento de bovinos da raça Nelore no Mato Grosso do Sul. Revista Brasileira de Zootecnia. 2004;33(6), 1445-1455.

8. Alencar MM,Mascioli AS,Freitas AR. Evidências de interação genótipo - ambiente sobre características 
de crescimento em bovinos de corte. Revista Brasileira de Zootecnia. 2005;34(2), 489-495.

9. de Almeida Teixeira R, de Albuquerque LG, de Alencar MM, Dias LT. Interação genótipo-ambiente em cruzamentos de bovinos de corte. Revista Brasileira de Zootecnia. 2006;35(4), 1677-1683.

10. Fridrich AB, Silva MA, Valente BD, Sousa JE, Corrêa GS, Ferreira IC, Ventura RV, Silva LO. Interação genótipo x ambiente e estimativas de parâmetros genéticos dos pesos aos 205 e 365 dias de idade de bovinos Nelore. Arquivo Brasileiro de Medicina Veterinária e Zootecnia. 2008;60(4), 917-925.

11. IBGE - Instituto Brasileiro de Geografia e Estatística. Censo Agropecuário, Available in: <http://www.ibge.gov.br> Access in: August.2014;28.

12. SAS Institute Inc. Statistical Analysis System user's guide. SAS Institute Press, 2002, USA. Disponível em

https://support.sas.com/documentation/cdl/en/statugintroduction/61750/PDF/default/statugintroduction.pdf.

13. Boldman KG,Kriese LA,Van Vleck LD. A manual for use for MTDFREML. A set of programs to obtain estimates of variance and covariance [DRAFT]. 1995. Lincoln: Department of Agriculture/Agricultural Research Service.

Disponível

em

:https://www.researchgate.net/profile/Lloyd Van Vleck/publication/281307227 A Manual for Use of M TDFREML_a_Set_of_Programs_to_Obtain_Estimates_of_Variances_and_Covariances_draft/links/55e5f4 8808aebdc0f58bab17.pdf . Acesso em novembro de 2016

14. Lin $\mathrm{CH}$, Togashi $\mathrm{K}$. Genetic improvement in the presence of genotype by environment interaction. Journal Animal Science. 2002;73(1), 3-11.

15. Blackburn H,Lebbie SHB,Van De Zijpp AJ. Animal Genetic Resources and sustainable development. In: world congress on genetics applied to livestock production, 6, 1998, Armidale, Proceedings..., UNE, 6 WCGALP/FAO Symposium. 1998;28, 3-10.

16. Olesen I,Goren AF,Gjerde B. Definition of animal breeding goals for sustainable production systems. Journal Dairy Science. 2000;78(3, 570-582.

17. Pegolo NT. Interação genótipo-ambiente e sensibilidade ambiental em bovinos de corte. Ribeirão Preto, 2009. 115 p. (PhD Thesis) - Faculdade de Medicina de Ribeirão Preto, Universidade de São Paulo, Ribeirão

Preto, SP. $\quad$ Disponível em http://repositorio.unesp.br/bitstream/handle/11449/95335/pegolo nt me botfmvz.pdf?sequence=1

18. Dal-FARRA RA,Roso VM,Schenkel FS. Efeitos de ambiente e heterose sobre o ganho de peso do nascimento ao desmame e sobre os escores visuais ao desmame de bovinos de corte. Revista Brasileira de Zootecnia. 2002;31(3), 1350-1361.

19. Hammond K. The status, state and conservation of animal genetic resources. FAO, Rome (Mimeo) 1993. 86.

20. Smith C. Genetic aspects of conservation in farm livestock. Livestock Production Science. 1984;11(6), $37-48$.

21. Espasandin AC, Urioste JI, Campos LT, Alencar MMD. Genotype $\times$ country interaction for weaning weight in the Angus populations of Brazil and Uruguay. Revista Brasileira de Zootecnia. 2011;40(3), 568574.

22. Willham RL. The role of maternal effects in animal breeding: III. Biometrical aspects of maternal effects in animals. J Anim Breed Genet. 1972;35: 1288-1293 